\title{
Structural heart disease: the revolution
}

To understand why the Annals of Translational Medicine is interested in a special series on structural heart disease we should remember the exciting key points in the history of one of the most important innovations of cardiology to date, the transcatheter aortic valve implantation (TAVI).

Transcatheter valvuloplasty began in the 80 s to treat pulmonary, mitral and aortic stenosis. Pulmonary and mitral valvuloplasty showed low rate of reoperation and good long-term outcomes. However, aortic valvuloplasty soon demonstrated its inability to modify the natural history of the severe aortic stenosis (SAS) (1). Common belief was that this technique failed because all calcium had to be removed.

However, because around a quarter of patients with SAS could not be operated, the development of percutaneous aortic valves did not stop and Cribier published in 2002 the first implantation of this kind of prosthesis (2). Nevertheless, the calcium could not be removed so its ability to modify the natural history of this disease was uncertain.

In 2010 and 2011 randomized controlled trials (RCT) showed that, not only TAVI modified the natural history of SAS but also, they achieved same survival than surgery for high-risk patients in mid-term follow-up $(3,4)$. However, paravalvular regurgitation, pacemaker implantation and vascular complications were much higher in TAVI than surgery. So, nothing suggested that these techniques could be used in other patients in the future. It was somehow logical. How a valve with no sutures could be used if calcium was not removed, knowing that even removing it, surgeons need to give 15-20 robust stitches to the aortic annulus to avoid displacement and leakage?

In 2016 and 2017, new clinical trials showed same or even better survival for intermediate risk-patients with TAVI compared with surgery $(5,6)$. Pacemaker, vascular complications and aortic regurgitation had been surprisingly reduced. However, most of us thought that surgery was going to be always the gold-standard treatment for SAS. To understand this thought, we should put in context what kind of patients formed these clinical trials (7). Intermediate risk patients, those who formed these RCT, were chosen if they presented an STS risk score between 4 and 8 and even some of them had more than 8 . My institution participated in one of these RCT and we knew how difficult in real life was to find a patient with an STS risk score over 4. Not in vain, almost $80 \%$ of patients with SAS were low-risk. Let's put an example. An octogenarian male patient in dialysis, with arteriopathy and immunocompromised has a calculated risk-score for isolated AVR of $3.9 \%$, so its low-risk.

Incredibly, TAVI technique and technology experienced such rapid improvement that there are few parallels in the history of Cardiology. Recently, the two largest RCT comparing TAVI to surgery in low-risk patients, STS $<4$, were published $(8,9)$. No difference was found between surgery and TAVI for one type of the transcatheter prosthesis and lower mortality was shown for the other one. Accordingly, surgical risk is no longer a key factor when deciding the best treatment for a patient with SAS. Rather, the balance between life expectancy and prosthesis degeneration is becoming the main factor to consider $(10,11)$. Although some simulation studies suggested that TAVI prosthesis could degenerate earlier than surgical valves, scientific evidence to date is suggesting that degeneration is not going to be a big problem for TAVI $(7,12)$. Another gap of knowledge is the performance of TAVI in bicuspid aortic valves since these patients were excluded from the main RCT and almost $50 \%$ of patients with SAS have bicuspid valves (10).

Although not with the same success, other transcatheter procedures to treat other valves have been also developed and are in continuous process of improvement. Percutaneous treatment of the mitral valve has also evolved. Specially for patients with secondary mitral regurgitation, the success of the percutaneous repair depends on the adequate election of the candidates. Imaging techniques play a key role in this case.

In this exciting series: "Structural heart disease: the revolution" some of the greatest experts of the world review the state of the art of these therapies and devices, share future challenges and publish interesting works.

\section{Acknowledgments}

Funding: None.

\section{Footnote}

Provenance and Peer Review: This article was commissioned by the editorial office, Annals of Translational Medicine for the series 
"Structural Heart Disease: The Revolution". The article did not undergo external peer review.

Conflicts of Interest: The author has completed the ICMJE uniform disclosure form (available at http://dx.doi.org/10.21037/ atm.2020.01.48). The series "Structural Heart Disease: The Revolution" was commissioned by the editorial office without any funding or sponsorship. DHV served as the unpaid Guest Editor of the series and serves as an unpaid editorial board member of Annals of Translational Medicine from Aug 2019 to Jul 2021.

Ethical Statement: The author is accountable for all aspects of the work in ensuring that questions related to the accuracy or integrity of any part of the work are appropriately investigated and resolved.

Open Access Statement: This is an Open Access article distributed in accordance with the Creative Commons AttributionNonCommercial-NoDerivs 4.0 International License (CC BY-NC-ND 4.0), which permits the non-commercial replication and distribution of the article with the strict proviso that no changes or edits are made and the original work is properly cited (including links to both the formal publication through the relevant DOI and the license). See: https://creativecommons.org/ licenses/by-nc-nd/4.0/.

\section{References}

1. Figulla HR, Franz M, Lauten A. The history of Transcatheter Aortic Valve Implantation (TAVI)-A personal view over 25 years of development. Cardiovasc Revasc Med 2020;21:398-403.

2. Cribier A, Eltchaninoff H, Bash A, et al. Percutaneous transcatheter implantation of an aortic valve prosthesis for calcific aortic stenosis: first human case description. Circulation 2002;106:3006-8.

3. Leon MB, Smith CR, Mack M, et al. Transcatheter aortic-valve implantation for aortic stenosis in patients who cannot undergo surgery. N Engl J Med 2010;363:1597-607.

4. Smith CR, Leon MB, Mack MJ, et al. Transcatheter versus surgical aortic-valve replacement in high-risk patients. N Engl J Med 2011;364:2187-98.

5. Leon MB, Smith CR, Mack MJ, et al. Transcatheter or Surgical Aortic-Valve Replacement in Intermediate-Risk Patients. N Engl J Med 2016;374:1609-20.

6. Reardon MJ, Van Mieghem NM, Popma JJ, et al. Surgical or transcatheter aortic-valve replacement in intermediate-risk patients. N Engl J Med 2017;376:1321-31.

7. Hernandez-Vaquero D, Díaz R, Álvarez-Cabo R, et al. Are transcatheter procedures the treatment of choice for all patients with severe aortic stenosis? J Cardiovasc Surg (Torino) 2017;58:132-3.

8. Mack MJ, Leon MB, Thourani VH, et al. Transcatheter Aortic-Valve Replacement with a Balloon-Expandable Valve in LowRisk Patients. N Engl J Med 2019;380:1695-705.

9. Popma JJ, Deeb GM, Yakubov SJ, et al. Transcatheter Aortic-Valve Replacement with a Self-Expanding Valve in Low-Risk Patients. N Engl J Med 2019;380:1706-15.

10. Otto CM. Informed Shared Decisions for Patients with Aortic Stenosis. N Engl J Med 2019;380:1769-70.

11. Diaz R, Hernandez-Vaquero D, Alvarez-Cabo R, et al. Long-term outcomes of mechanical versus biological aortic valve prosthesis: Systematic review and meta-analysis. J Thorac Cardiovasc Surg 2019;158:706-714.e18.

12. Hernández-Vaquero D, Díaz R, Pascual I, et al. Long-term Survival After Surgery Versus Transcatheter Technique to Treat Degenerated Aortic Bioprostheses. Rev Esp Cardiol (Engl Ed) 2019;72:878-80. 


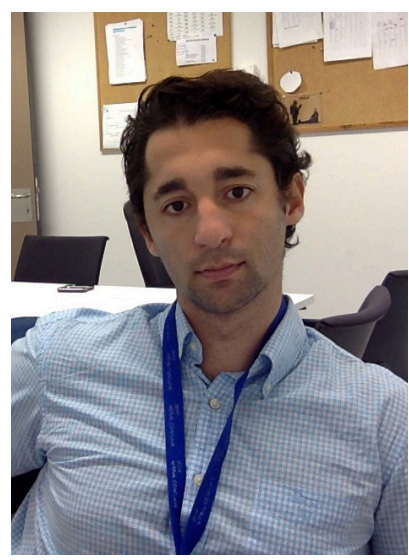

Daniel Hernandez-Vaquero

\section{Daniel Hernandez-Vaquero ${ }^{1,2,3}, \mathbf{M D}, \mathrm{PhD}$}

${ }^{1}$ Department of Cardiac Surgery, Hospital Universitario Central de Asturias, Oviedo, Spain; ${ }^{2}$ Instituto de Investigación Sanitaria del Principado de Asturias, Oviedo, Spain; ${ }^{3}$ Department of Phisiology, University of Oviedo, Oviedo, Spain.

(Email:dhvaquero@gmail.com)

Submitted Dec 11, 2019. Accepted for publication Jan 06, 2020. doi: $10.21037 / \mathrm{atm} .2020 .01 .48$

View this article at: http://dx.doi.org/10.21037/atm.2020.01.48

Cite this article as: Hernandez-Vaquero D. Structural heart disease: the revolution. Ann Transl Med 2020;8(15):954. doi: 10.21037/atm.2020.01.48 